\title{
Caste Microaggression: A Barrier to Lower Affective Filter and to Promote Inclusivityin the Classroom
}

Sangam Chaulagai

Lecturer of English

Makawanpur Multiple Campus

sangamhtd2040@gmail.com

Received: May 05, 2021; Revised \& Accepted: May 10, 2021; Published: June 30, 2021

(C) Copyright: Chaulagain (2021).

\begin{abstract}
This article explores the impact of caste microaggressions in classroom activitiesin the countries like Nepal. It focuses on the study of how caste microaggressions are barriers to lower affective filter and promote inclusivity in the classroom. This is a review article based on qualitative research in which the ideas are derived from different secondary sources and are arranged to support how lower-caste students are the victim of caste microaggressions in Nepali society. This article shows that the students of lower-caste families, especially the Dalits, are greatly victimized by discriminatory activities in the schools of rural areas of Nepal. To promote inclusivity and to encourage lower-caste children in learning activities, it is essential to avoid caste microaggression and to emotionally engage such students in classroom activities that have to be initiated by the teachers primarily.
\end{abstract}

\section{Key Words}

Affective filter, caste microaggression, classroom, Dalits, inclusivity, microaggressions, stereotype

\section{INTRODUCTION}

I still remember the days when I had been admitted to a school in a village in 1989 AD.

The students in our school were from multiple caste and ethnic backgrounds. Some the students were from so called untouchablecastes; we call Dalits in Nepal. The school used to provide snacks free of cost to all of the students. The students of those untouchable caste used to be kept separately while eating snacks so that they would not touch other higher caste students. The students of untouchable caste used to face lots of discriminatory behaviors inside and outside the classroom. The teachers were all from higher caste Brahman, Chhetri background and they were also the agents of discrimination, either knowingly or unknowingly. The students of those communities used to be called by using insulting and derogatory words and expressions.

I was the student of so-called higher caste family. Therefore, my innocent mind did not feel any uncomfortability with such discriminatory activities. I, now, realize how the children of 
lower caste used to be discriminated inside and outside the classroom. I also realize how much painful it would become for me if I were the child of untouchable parents. Those days have passed; and the situation has changed, but the signs of caste microaggressions can clearly be seen even today. In remote villages, the practice of untouchability is still prevailing and the lower caste students are still discriminated in schools. In city areas, we do not see direct discrimination, but we can find caste microaggressions if we make minute study of the cases. It means the students of untouchable caste have to face psychological and stereotypical discriminations from the teachers and other friends of higher caste in their school premises.

\section{Defining Microaggressions}

Sue (2010) in his book Microaggressions in Everyday Life: Race, Gender, and Sexual Orientation defined microaggressions as "brief and commonplace daily verbal, behavioral, and environmental indignities, whether intentional or unintentional, that communicate hostile, derogatory or negative racial, gender, sexual-orientation, and religious slights and insults to the target person or group" (p. 5). Lilienfeld (2017) described microaggressions "as subtle snubs, slights, and insults directed toward minorities, as well as to women and other historically stigmatized groups, that implicitly communicate or engender hostility" (p. 139).

The term 'microaggression was first coined by psychiatrist and professor Chester M. Pierce in the 1970s. He used this term to describe the unintentional, negative remarks and expressions non-black people said to black people in higher education and white-collar jobs (Gabay, 2020). Although microaggressions are sometimes rebuffed by the target, they must often be accepted without challenge because of the power differential between the parties. Thetargets are the victimized people who learn that if they reject microaggressive actions, they may experience social harm in the form of anger, defensiveness, and/ or denial from the offender (DiAngelo, 2011; Sue et al., 2007). In that sense, the targets are typically forced to endure these insults without resistance because it can contribute to the perpetuation of the problem.

Lilienfeld (2017) interpreted the prefix "micro" in microaggression to mean that the misbehavior is "barely visible or at least challenging to detect" (p. 158). The word "micro" is simply meant to contrast with "macro". A macroaggression would be a racist act resulting in tangible harm, such as an assault or losing one's job (Pierce, 1970). The operation of microaggression may not be overtly visible to the people; it lies in the psychology of the people and is articulated indirectly through expressions and actions. If it brings any overt consequence, that can be called macroaggression.

Sue et al. (2007) created three classifications of microaggressions. Those three classifications, according to him, are microassaults, microinsults, and microinvalidations. Microassults are considered intentional behaviors, whereas microinsults and microinvalidations are not intended to be offensive. It has also been argued that microassaults do not capture the true definition of microaggressions because they are intentionally meant to cause harm whereas the others are not (Lilienfeld, 2017b). In microinsults, there is disrespect to the target for being a person of inferior status. Microinvalidations are hurtful because they invalidate the thoughts, 
feelings, or experiences of the target as a person of inferiority. But both microinsults and microinvalidations are unintentional and are covertly harmful.

Pierce (1995) argues that microaggressions are the everyday, minor, and apparently innocuous 'degradations, and put-downs' experienced by members of oppressed, systematically disadvantaged or marginalized groups. The innocence of the target makes it minor and less harmful to them. Even where they are not minor acts, the behaviors are still subtle, so that they appear innocuous in their context, say by being hard to detect (McTernan, 2018).

Microaggressions form a social practice that contributes to structures of oppression and marginalization(Lindsay \&Solorzano, 2015). Through microaggressions the powerful community dominates and controls over the powerless community. Microaggressions might take place in different forms; for example, there are gender microaggressions, class microaggressions, racial microaggressions, religious microaggressions, caste microaggressions, cultural microaggressions and others.

\section{Caste Microaggressionsand Nepali Classrooms}

Sue (2010) believed that microaggressions increase the risk of mental health issues and play a significant role in poor academic achievement in many minority populations. The exclusion of lower-caste people in educational and other socio-economic opportunities has created operation and marginalization to the students of those communities inside and outside the classroom.Rao (2013) noted that the lower caste students and particularly Dalit students face various subtle and explicit forms of discrimination in the institution. Dalit students are often the victims of humiliation, insultation and offensive behaviors in direct or indirect wayduring teaching and learning activities. Such kind of degradation and marginalization is called caste microaggression.

Microaggression theory (Sue et al., 2007) is a relevant theory to the study of discrimination experienced by the lower caste students. Caste based discriminations are typical cases in South Asia, specifically in India and Nepal. Hanna and Linden (2009) study about the caste discrimination in the classrooms in India and find the evidence that teachers discriminate against low caste children in grading exams. Among the lower caste groups, Dalit and Tribal students have experienced intensified humiliation, segregation, derogatory comments and academic harassment (Sukumar, 2008).Deriving the reference of India regarding the attitude of upper-caste people, Kent (2005) argues that people from upper-caste groups are more likely to claim that caste discrimination no longer exists in India, while members of low-caste groups know from experience that it does. Not only in India, caste-based discrimination is strongly recognized in Nepal that has excluded Dalits from educational as well as socio-economic opportunities (Devkota\&Bagale, 2014).

Researches show that teachers have also become the agents for microaggressions in schools. Perceptions of discrimination from teachers are associated with low grades, motivation, and less persistence when ethnic minority students are faced with academic challenges (Stone \& Han 2005) Caste-based discriminatory attitudes of non-Dalits in the school context are mainly 
revealed in relation to a lack of willingness to share food and drinks with the Dalits (Khanal, 2015). The research of Khanal (2015) reveals that some traditional and elderly teachers of upper caste are still unwilling to share food and drinks to the Dalit students. This kind of microaggression discourages Dalit students in learning activities and hoping for better future. Due to this kind of situation, some Dalit parents do not send their children to the school even if their child has received a scholarship (ERDCN, 2011). With low expectations of education, parents are often reluctant to spend for their children's education.

Lower-caste children in Nepal are highly victimized by caste microaggressions as Markos and Mc Whinney (2003) stated that marginalized people are ignored and restricted for education. Though people may not see it explicitly, in subtle level, the children of lower-caste community, especially Dalits are humiliated and degraded physically, psychologically, culturally and socially.Pivovarova (2010) has reported that caste-based discrimination is practiced at schools in various forms. These kinds of situation increases affective filter in learning; challenges the philosophy of inclusivity and devalues the presence of lower-caste students in the school premises.

\section{Caste Microaggression as Affective Filter in the Classroom}

$\mathrm{Du}(2009)$ states that the affective filter acts as a barrier to acquisition. He opines that the filter is up when the acquirer is unmotivated, lacking in confidence, or concerned with failure and the filter is down when the acquirer is not anxious and is filled with motivation and confidence. Affective filter hypothesis is first proposed by Dulay and Burt (1977), and is incorporated by Krashen as one of his five input Hypotheses in 1985. Krashen's affective filter hypothesis (1985) suggests that language learners might be distracted by emotional factors in language learning process. It is possible that students would not be able to absorb what they should learn in class because of their teacher's uncongenial manners or classmates' aggressive and competitive attitudes.

Krashen discusses the affective filter relating it to Second Language Acquisition. In his affective filter hypothesis, Krashen (1982) points out that in Second Language Acquisition (SLA), much key factors of learners' success in language learning should be associated to the student's emotional condition. A language learner's passion of participating the class and confidence from teachers' encouragements can decide the accomplishment of their SLA. People with high affective filter will lower their intake whereas people with low affective filter allow more input into their language acquisition device $(\mathrm{Du}, 2009)$. It shows that in addition to some objective factors, there are also some affective factors in language learning that filtrates the amount of input in learners' brains.

Krashen has mentioned that there are mainly four factors that can influence the SLA which are responsible for the individual variation. The four factors are Motivation, Attitude, Anxiety and self-confidence (Du,2009). Schinke-Llano and Vicars (1993) argue that low anxiety and low stress environment for language learning with a low affective filter are considered to be necessary conditions for successful additional language acquisition. The work of Lin (2008) 
showcases the importance of reducing the affective filter through a nurturing instructional style characterized by high levels of instructor praise and encouragement. Richards and Rodgers (2014) also posit that a low affective filter can facilitate an English language learner to absorb, practice, and produce the target language efficiently.

The effect of teaching not only results from the text book, the teacher's quality, the difficult theory but also has connection with the learners' affective factors. The ignorance of the relationship between the students' affective factors and their learning will have negative influence on the teaching and learning effect $(\mathrm{Du}, 2009)$. The more encouraged and motivated the learners are, the less the affective filter will become. The more the affective filter will reduce, the more efficient teaching and learning becomes.

In the context of Nepal, caste microaggression is one of the major factors that hinders the efficiency of lower-caste students' learning. Rao (2010) stated that Dalit students are not allowed to sit next to the high caste children in the class in certain remote area of Nepal. In the same manner, Wagle (2012) also stated that Dalit students sit separately in some rural schools, as a result, they are left to stand at the back of the classroom. Dalit children are also blamed to be slow learners and weaker performers. Such kind of constraint forces them to feel school as an unpleasant part of the society. Thelower-caste students are often the victims of stereotypes inside and outside the classroom by their colleagues, seniors, and even by higher-caste teachers.Multiple studies have found that stereotype threat significantly reduces performance for undergraduates from less privileged socioeconomic statuses (Croizet\& Claire, 1998; Spencer \& Castano, 2007). The students of the Dalit, so called untouchable, are further victimized with such stereotypes. Some of the high-caste people do not eat food and do not drink water touched by the so-called untouchable people. In some rural villages the children of Dalit community are asked to clean their utensils themselves andare asked to keep separately. Therefore, they are less preferred in discussion, asking questions, and other classroom activities. The inferiority complex of those children keeps them backward in learning activities.

There are so many proverbs and idioms that are popularly used in Nepali society which represent negative stereotypes of Dalit people. Some of those proverbs and idioms are given below:

1. MarepaxiDumai Raja

2. Hami vanekohami ho, aruvaneko Kami ho

3. AghipachhiaauneDamai Kami, AhileaauneDeusehami

4. Kamikobehulo

5. Chyamekobachcha

6. EknumberkoChamar

These negative stereotypes related to Dalit people are also used metaphorically to insult and scold other non-Dalit people. Dalit children are often scolded and insulted by their friends and teachers using such idioms and proverbs either intentionally or unintentionally. These kinds of insulting and humiliating expression discourage Dalit children in learning activities. The study 
of Khanal (2015) revealed that Dalits say 'we are not going to be a Doctor or an Engineer therefore as long as we are able to read and write, it is enough for us, so we don't want to educate our children anymore.' This expression shows how discouraged and demotivatedDalit parents are regarding the future progress of their children. The study of Khanal (2015) further reports about Dalit people; who say that even if they studied, they still have to do the same labor work throughout their life. This view shows that there is a lack of quality employment opportunities for Dalits in Nepali society. These all references show that caste microaggression is an affective filter that obstructslearning achievement.

\section{Creating Inclusivity in the Classroom}

The issue of caste discrimination has long run history and has been deeply rooted as a culture in the society. It seems to have decreased gradually, but it is hard to uproot socially and culturally. Instead, it has been appearing in various forms and conditions. Historical perspectives on the categories of caste and race indicate that these social categories are continuously evolving (Quigley 1993; Gupta 2000). The issues of caste and race are still considered to be static and this mentality is the challenge for inclusivity in the society. Several studies show that the students of less privileged and more marginal backgrounds face greater challenges as they enter the classes because they can perceive to be an unwelcoming or even hostile environment (Carter, Locks, Winkle-Wagner, \& Pineda, 2006; Kalsner\& Pistole, 2003).

Changing inappropriate student behavior requires changing the teachers' behavior (Scheuermann \& Hall, 2012). Rosenthal and Jacobson (1968) found that the teachers' beliefs about the student performance and ability could be subtly manipulated to make them believe that some students are better than their peers. This kind of manipulation of teachers' psychology is a challenge for creating inclusivity in the classroom. Reynolds (2009) opines that an accomplished teacher is a critical influence whose knowledge, beliefs and values can be brought in creating an effective learning environment for pupils which is inclusive. It shows that teachers are the real actors and agents for creating inclusivity within the classroom.

One of the challenges of inclusivity is stereotype threat, which refers to the fear of confirming a negative stereotype about their respective in-group, a fear that can create high cognitive load and reduce academic focus and performance (Steele \& Aronson, 1995). The effects of stereotype threat are profound and can impact students in various ways for their confident performance. Stereotype threat is especially detrimental for individuals who identify strongly with the stigmatized group (Marx, Stapel, \& Muller, 2005). Identifying and eliminating stereotype threat should be a central goal for teachers who want to increase inclusivity in the classroom. The teachers need to be aware of the classroom environment to be sure that no one has been victimized by stereotypical threat.

School must be able to provide safe and protected environment, where a student can come and learn without fear (Wong \&Wong, 2014). Student victims of an unwelcoming classroom climate are at risk for psychological stress, decreased self-esteem, reduced participation, diminished academic performance, and decreased persistence (Hotchkins\& Dancy, 
2015). Research suggests that class discussions are effective in ameliorating the negative effects of microaggressions (Boysen, 2012; Sue et al., 2011).

Williams et al. (2005) propose the following points for creating inclusivity in the classroom:

1. Focusing on students' intellectual and social development; offering the best possible course of study for the context in which the education is offered.

2. Purposely developing and using educational resources to enhance students' learning; establishing an environment that challenges each student to achieve at high levels academically while encouraging each member of the class to contribute to students' overall learning and knowledge development.

3. Paying attention to the cultural differences diverse learners bring to the educational experience and how those cultural differences enhance the teaching and learning environment.

4. Creating a welcoming classroom environment that engages all of its diversity in the pursuit of individual and collaborative learning.

Inclusivity can eated in the classroom only by the sincere initiatives of the teachers. The teachers, first, need to be aware of microaggressions and should commit him/herself not to be the agent of microaggressions. Similarly, involving the learners in group activities and mixing the learners of different castes and communities in the activities can encourage them for inclusivity. Zirpoli (2012) argues that pulling reinforcers or privileges away comes with an emotional cost. Teachers' emotional engagement with the learners of lower caste and underprivileged group to empathize them, and constant encouragement for them in learning activities can be some healing medicines to lower affective filter and to promote inclusivity.

\section{CONCLUSION}

This article provides insight to the teachers and other teaching professionals to avoid the actions and activities related to affective filter and microaggressions and to create inclusivity in the classroom. Out of various microaggressions existing in society as a usual exercise, caste microaggression is one of the serious microaggressions that has obstructed the people of lower caste, especially Dalits, in their career building primarily in the countries of South Asia. Talking about the classrooms of rural villages in the countries like Nepal, the students of so-called untouchable communities are still the victim discrimination. Such kind of discriminatory activities are performed by the teachers and colleagues of upper-caste families. Caste microaggression has playeda role of catalyst to increase affective filter and to create barrier in learning achievement to the students of lower-caste, and more specifically the Dalits.

There are several stereotypical expressions prevailing in Nepali society which denounce and discourage Dalits. The innocent children of schools are also intentionally or unintentionally the victims of such stereotypes. Even the teachers are found to be using such stereotypical expressions to lower-caste students. Avoiding such stereotypical expressions inside and outside the classroom and emotionally engaging the students of underprivileged groups are essential for creating inclusivity in teaching and learning activities. Avoiding caste microaggressions, 
lowering affective filter and promoting inclusivity are essential aspects in classroom activities so as to create justice and equity in school education.

\section{REFERENCES}

Alabi, J. (2015). Racial microaggressions in academic libraries: Results of a survey of minority and non-minority librarians. Journal of Academic Librarianship, 41, 47-53.

Boysen, G. A. (2012). Teacher and student perceptions of microaggressions in college classrooms. College Teaching, 60(3), 122-129. doi:10.1080/87567555.2012.654831

Carter, D. F., Locks, A. M., Winkle-Wagner, R., \& Pineda, D. (2006, April). "From when and where I enter": Theoretical and empirical considerations of minority students 'transition to college. Paper presented at American Educational Research Association annual meeting, San Francisco.

Croizet, J. C., \& Claire, T. (1998). Extending the concept of stereotype threat to social class: The intellectual underperformance of students from low socioeconomic backgrounds. Personality and Social Psychology Bulletin, 24, 588-594.

Devkota, S. P., \&Bagale, S. (2014). Discourse of inclusive education from Dalit perspectives in Nepal.Participation, 16(15), 39-45.

DiAngelo, R. (2011). White fragility. The International Journal of Critical Pedagogy, 3(3), 5470.

Du, X. (2009). The affective filter in second language teaching. Asian Social Science, 5(8), 161165.

Dulay, H., \& Burt. M. (1977). Remarks on creativity in language acquisition. In M. Burt, H. Dulay \& M. Finocchiaro (Eds.). Viewpoints on English as a second Language. New York: Regents.

ERDCN (Educational Resource and Development Centre Nepal). (2011). A study on effectiveness of girls' scholarship programme submitted to the department of education. Kathmandu: Educational Resource and Development Centre Nepal (ERDCN).

Gabay, D. (2020). reducing microaggressions by educators onto students in primary education setting. Doctoral Dissertation presented to the Alliant International University, Los Angeles.

Gabay, D. (2020). Reducing microaggressions by educators onto students in primary education setting (Doctoral dissertation). Alliant International University, Los Angeles.

Gupta, D. (2000).Interrogating caste: Understanding hierarchy and differencein Indian society. New Delhi: Penguin.

Hanna, R., \&Linden, L. (2009). Measuring discrimination in education. NBER Working Paper No. 15057. Cambridge MA 02138. 
Hotchkins, B.K., \& Dancy, T. E. (2015). Black male student leaders in predominantly white universities: Stories of power, preservation, and persistence. Western Journal of Black Studies, 39(1), 22-34.

Huber, L. P. \& Solorzano, D. G. (2015). Visualizing everyday racism: critical race theory, visual microaggressions, and the historical image of Mexican banditry. Qualitative Inquiry, 21, 223-38.

Kalsner, L., \& Pistole, M. C. (2003). College adjustment in a multiethnic sample: Attachment, separation-individuation, and ethnic identity. Journal of College Student Development, 44(1), 92-109.

Kent, E.F. (2005). Representing caste in the classroom: Perils, pitfalls and potential insight. Method \& Theory in the Study of Religion, 17, 231-241.

Khanal, D. (2015). Children from the Dalit community in rural Nepal: A challenge to inclusive education. International Journal of Inclusive Education, 19(7), 710-720.

Krashen, S. D. (1982). Principles and practice in second language acquisition. New York: Prentice-Hall International.

Krashen, S. D. (1985). The input hypothesis: Issues and implications. New York: Longman.

Lilienfeld, S. O. (2017). Microaggressions: Strong claims, inadequate evidence. Perspectives on Psychological Science, 12, 138-169. doi:10.1177/1745691616659391

Lin, G. H. C. (2008). Pedagogies proving Krashen's theory of affective filter. Journal of English Language \& Literature, 14, 113-131.

Markos, L. \&McWhinney, W. (2003). Editors' perspectives: Auspice. Journal ofTransformative Education, 1(1), 3-15.

Marx, D.M., Stapel, D.A, \& Muller, D. (2005). We can do it: The interplay of construal orientation and social comparisons under threat. Journal of Personality and Social Psychology. 88, 432-446.

McTernan, E. (2018). Microaggressions, equality, and social practices. The Journal of Political Philosophy, 26(3), 261-281.

Pierce, C. (1970). Offensive mechanisms. In F. B. Barbour (Ed.), The Black seventies (pp. 265282). Boston, MA: Porter Sargent.

Pierce, C.(1995).Stress analogs of racism and sexism. Mental Health, Racism and Sexism. In C. V. Willie, P. P.Rieker, B. M. Kramer, and B. S. Brown (Eds.). Pittsburgh: University of Pittsburgh Press,pp. 277-93.

Pivovarova, M. (2010). Caste, gender and school enrolment: Evidence from the Nepalese living standard survey.http://individual.utoronto.ca/pivovarova/research/paper.pdf

Quigley, D. (1993).The Interpretation of Caste. New Delhi: Oxford University Press.

Rao, J. (2010). The caste system: Effects on poverty in India, Nepal and Sri Lanka. Global Majority E-Journal, 1(2), 97-106. 
Rao, S.(2013). Structural Exclusion in Everyday Institutional Life: Labelling of Stigmatized Groups in an IIT. Sociology of education in India: Changing contours and emerging concerns (pp. 199-223). New Delhi: Oxford University Press.

Reynolds, M. (2009). Education for inclusion, teacher education and the teacher training agency standards. Journal of In-Service Training, 27 (3).

Richards, J. C., \& Rodgers, T. S. (2014). Approaches and methods in language teaching. Cambridge, UK: Cambridge University Press.

Rosenthal, R., \& Jacobson, L. (1968). Pygmalion in the classroom: Teacher expectations and pupils' intellectual development. New York:Holt, Rinehart, \& Winston.

Scheuermann, B., \& Hall, J. (2012). Positive behavioral support for the classroom (2nd ed.). Upper Saddle River, NJ: Pearson.

Schinke-Llano, L.,\& Vicars, R. (1993). The affective filter and negotiated interaction: Do our language activities provide for both? The Modern Language Journal, 77, 325-329.

Spencer, B., \& Castano, E. (2007). Social class is dead. Long live social class! Stereotype threat among low socioeconomic status individuals. Social Justice Research, 20, 418 - 432.

Steele, C.M., \& Aronson. J. (1995). Stereotype threat and the intellectual test performance of African Americans. Journal of Personality and Social Psychology, 69, 797-811.

Stone, S., \& Han, M. (2005). Perceived school environment, perceived discrimination, and school performance among children of Mexican immigrants. Child Youth Serv Rev, 27(1), 51-66.

Sue, D. W., Capodilupo, C. M., Torino, G. C., Bucceri, J. M., Holder, A. M., Nadal, K. L., . . . Esquilin, M. E. (2007). Racial microaggressions in everyday life: Implications for counseling. American Psychologist, 62, 271-286.

Sue, D. W. (2010). Microaggressions in everyday life: race, gender, and sexual orientation. Hoboken, N.J.: Wiley.

Sue, D. W., Rivera, D. P., Watkins, N. L., Kim, R. H., Kim, S., \& Williams, C.D. (2011). Racial dialogues: Challenges faculty of color face in the classroom. Cultural Diversity \& Ethnic Minority psychology, 17(3), 331-340.

Sukumar, N.(2008). Living a concept: semiotics of everyday exclusion. Economic and Political Weekly, 43(46),14-17.

Wagle, D. (2012). Dropout of children from school in Nepal. Master's thesis submitted to Faculty of Science and Technology Management, Norwegian Centre for Child Research (NOSEB).

Williams, D. A., Berger, J. B., \& McClendon, S. A. (2005). Toward a model of inclusive excellence and change in postsecondary institutions. Washington, DC: Association of American Colleges \& Universities.

Wong, H., \& Wong, R. (2014). The classroom management book. Mountainside, CA: Wong Publishing. 